Bull. Mater. Sci., Vol. 22, No. 4, June 1999, pp. 821-826. (C) Indian Academy of Sciences.

\title{
Nucleation studies in supersaturated aqueous solutions of urea and thiourea doped with inorganic dopants
}

\author{
J M KAVITHA, K SEETHALAKSHMI, C MAHADEVAN* and Y PREMILA. RACHELIN \\ Department of Physics, Scott Christian College, Nagercoil 629 003, India \\ *S.T. Hindu College, Nagercoil 629002 , India
}

MS received 16 January 1999; revised 19 March 1999

\begin{abstract}
Induction periods were measured for various supersaturated aqueous solutions of urea doped separately with $\mathrm{NH}_{4} \mathrm{NO}_{3}$ and $\mathrm{NaNO}_{3}$ and thiourea doped separately with $\mathrm{NaCl}$ and $\mathrm{KCl}$ by the direct vision method. Based on classical theory for homogeneous crystal nucleation various critical nucleation parameters were calculated and the results are reported and discussed. In all the cases, the critical nucleation parameters increased with increase in doping concentration.
\end{abstract}

Keywords. Nucleation parameters; doped urea; thiourea crystals.

\section{Introduction}

Nucleation process is the initial and most important phenomenon in liquid-solid phase transition. Based on the classical theory for homogeneous crystal nucleation certain critical nucleation parameters like interfacial tension $(\sigma)$ of the solid relative to its solution, energy of formation $(\Delta G)$ of a critical nucleus, and radius of the nucleus $(r)$ in equilibrium with its solution can be calculated using the induction period $(\tau)$ which can be measured (Shanmugham et al 1984; Mullin 1993; Ramesh and Mahadevan 1998).

Urea $\left(\mathrm{NH}_{2}-\mathrm{CO}-\mathrm{NH}_{2}\right)$ belongs to the tetragonal crystal system. The unit cell has the dimensions given as $a=b=5.645 \AA$ and $c=4.704 \AA$ and two molecules (ASTM file). Urea is highly soluble in water and its solubility at $17^{\circ} \mathrm{C}$ is 100 parts by weight per 100 parts by weight of water. Its molecular weight and density are 60.06 and $1.335 \mathrm{~g} / \mathrm{cc}$ respectively (John 1979).

Thiourea $\left(\mathrm{NH}_{2}-\mathrm{CS}-\mathrm{NH}_{2}\right)$ belongs to the orthorhombic crystal system. The unit cell has the dimensions given as $a=5.50, b=7.68$ and $c=8.57 \AA$ and four molecules (ASTM file). Thiourea is soluble in water and its solubility at $13^{\circ} \mathrm{C}$ is 9.2 parts by weight per 100 parts by weight of water. Its molecular weight and density are 76.12 and $1.405 \mathrm{~g} / \mathrm{cc}$ respectively (John 1979).

An attempt has been made in the present study to determine the nucleation parameters of pure urea and thiourea crystals and also to investigate the effect of some inorganic substances as added impurities (impurity concentration in the range $2000-10000 \mathrm{ppm}$ ) on the nucleation parameters of these crystals.

\footnotetext{
*Author for correspondence
}

Urea was doped with ammonium nitrate $\left(\mathrm{NH}_{4} \mathrm{NO}_{3}\right)$ and sodium nitrate $\left(\mathrm{NaNO}_{3}\right)$ (both are denser than urea) separately each in six different urea : dopant molecular ratios, viz. $1: 0.0$ (pure urea), $1: 0.002,1: 0.004,1: 0.006$, $1: 0.008$ and $1: 0.010$. Similarly, thiourea was doped with sodium chloride $(\mathrm{NaCl})$ and potassium chloride $(\mathrm{KCl})$ (both are denser than thiourea) separately each in six different thiourea: dopant molecular ratios, viz. $1: 0 \cdot 0$ (pure thiourea), $1: 0.002,1: 0.004,1: 0.006,1: 0.008$ and $1: 0.010$. Induction periods were measured for various supersaturated solutions by the direct vision method. Various critical nucleation parameters have been calculated and the effect of supersaturation and concentration of doping on them is also reported and discussed.

\section{Experimental}

Analytical reagent grade (AR) samples of urea, thiourea, $\mathrm{NH}_{4} \mathrm{NO}_{3}, \mathrm{NaNO}_{3}, \mathrm{NaCl}$ and $\mathrm{KCl}$ along with doubledistilled water were used in the present study. Aqueous solutions of various supersaturations (S) $(1.225,1.250$, $1.275,1.300,1.325$, etc for urea and $1.45,1.50,1.55$, $1.60,1.65$, etc for thiourea) were prepared by dissolving the required amount of urea or thiourea and the dopant at a temperature slightly higher than the saturation temperature $\left(35^{\circ} \mathrm{C}\right)$. Supersaturation was obtained by natural cooling.

Induction periods were measured and the critical nucleation parameters were calculated following the procedures adopted by Ramesh and Mahadevan (1998). The experimental set-up used by us for induction period $(\tau)$ measurement consists of two identical nucleation cells ( $100 \mathrm{ml}$ beakers of corning glass) kept at a constant temperature of $35^{\circ} \mathrm{C}$ (controlled to an accuracy of 
$\pm 0 \cdot 1^{\circ} \mathrm{C}$ ). One of the cells was used as dummy. (As insertion of thermometer in the experimental cell may disturb the system, this dummy cell was used for keeping the sensitive thermometer.) Using a powerful lamp, the cells were illuminated. Supersaturated aqueous solutions of equal volume ( $20 \mathrm{ml}$ in the present work) were taken in the cells at a slightly higher temperature. A sensitive thermometer (accuracy $\pm 0 \cdot 1^{\circ} \mathrm{C}$ ) was placed in the dummy cell. As the cell attained experimental temperature (i.e. $35^{\circ} \mathrm{C}$ ), the time was noted. Once nucleation occurred, it grew quickly and a bright sparkling particle was seen. The time of observation of the sparkling particle in the undisturbed nucleation cell from the time at which the nucleation cell reached the experimental temperature gave the induction period. It was measured in seconds. Several nucleation runs were carried out under controlled and unstirred conditions and reproducible results within an accuracy of $\pm 2.5 \%$ were obtained.

Table 1. Results of induction period measurements for pure and doped urea.

\begin{tabular}{|c|c|c|c|}
\hline \multirow[b]{2}{*}{$\begin{array}{l}\text { Doping } \\
\text { ratio }\end{array}$} & \multirow[b]{2}{*}{$* S$} & \multicolumn{2}{|c|}{$\tau(\mathrm{sec})$ for } \\
\hline & & $\begin{array}{c}\mathrm{NH}_{4} \mathrm{NO}_{3} \text {-doped } \\
\text { urea }\end{array}$ & $\begin{array}{c}\mathrm{NaNO}_{3} \text {-doped } \\
\text { urea }\end{array}$ \\
\hline \multirow[t]{5}{*}{ Pure urea } & $1 \cdot 225$ & 4200 & 4200 \\
\hline & $1 \cdot 250$ & 2830 & 2830 \\
\hline & $1 \cdot 275$ & 1631 & 1631 \\
\hline & $1 \cdot 300$ & 1015 & 1015 \\
\hline & $1 \cdot 325$ & 600 & 600 \\
\hline \multirow[t]{5}{*}{$1: 0.002$} & $1 \cdot 225$ & 3310 & 3780 \\
\hline & $1 \cdot 250$ & 2400 & 2603 \\
\hline & $1 \cdot 275$ & 1255 & 1365 \\
\hline & $1 \cdot 300$ & 810 & 830 \\
\hline & $1 \cdot 325$ & 495 & 425 \\
\hline \multirow[t]{5}{*}{$1: 0.004$} & $1 \cdot 225$ & 2820 & 3435 \\
\hline & $1 \cdot 250$ & 1680 & 2280 \\
\hline & $1 \cdot 275$ & 900 & 1104 \\
\hline & $1 \cdot 300$ & 600 & 616 \\
\hline & $1 \cdot 325$ & 385 & 315 \\
\hline \multirow[t]{5}{*}{$1: 0.006$} & $1 \cdot 225$ & 2425 & 3060 \\
\hline & $1 \cdot 250$ & 1200 & 1740 \\
\hline & $1 \cdot 275$ & 720 & 923 \\
\hline & $1 \cdot 300$ & 410 & 525 \\
\hline & $1 \cdot 325$ & 240 & 238 \\
\hline \multirow[t]{5}{*}{$1: 0.008$} & $1 \cdot 225$ & 1740 & 2412 \\
\hline & $1 \cdot 250$ & 785 & 1500 \\
\hline & $1 \cdot 275$ & 440 & 774 \\
\hline & $1 \cdot 300$ & 343 & 423 \\
\hline & $1 \cdot 325$ & 120 & 180 \\
\hline \multirow[t]{5}{*}{$1: 0 \cdot 010$} & $1 \cdot 225$ & 1145 & 1875 \\
\hline & 1.250 & 630 & 1200 \\
\hline & 1.275 & 315 & 476 \\
\hline & $1 \cdot 300$ & 120 & 280 \\
\hline & $1 \cdot 325$ & 50 & 100 \\
\hline
\end{tabular}

*Saturated concentration for urea is $9.0489 \mathrm{M}$.
The direct vision method is not very accurate and does not involve rigorous methodology to study nucleation. The nuclei are non-observable even by microscopy; at the observable level, they are already at the growth stage. It is assumed that the time required for the critical nucleus to grow to an observable level is very small when compared to the induction period, and is negligible. Despite all these problems, this method was considered as no other better method is available to study nucleation in supersaturated solutions of highly soluble substances. Moreover, to reduce inaccuracy, the supersaturated concentration considered was ensured to provide the induction period more than $50 \mathrm{sec}$ at least. The effect of heterogeneous nucleation by dust particles from air was reduced by carrying out the experiments in a relatively dust-free space. Also, the effect of heterogeneous nucleation by scratchings on

Table 2. Results of induction period measurements for pure and doped thiourea.

\begin{tabular}{|c|c|c|c|}
\hline \multirow[b]{2}{*}{ Doping ratio } & \multirow[b]{2}{*}{$* S$} & \multicolumn{2}{|c|}{$\tau(\mathrm{sec})$ for } \\
\hline & & $\begin{array}{l}\mathrm{NaCl} \text {-doped } \\
\text { thiourea }\end{array}$ & $\begin{array}{c}\mathrm{KCl} \text {-doped } \\
\text { thiourea }\end{array}$ \\
\hline \multirow[t]{5}{*}{ Pure thiourea } & 1.45 & 1720 & 1720 \\
\hline & 1.50 & 1574 & 1574 \\
\hline & 1.55 & 1380 & 1380 \\
\hline & 1.60 & 1155 & 1155 \\
\hline & 1.65 & 915 & 915 \\
\hline \multirow[t]{5}{*}{$1: 0.002$} & 1.45 & 1150 & 1090 \\
\hline & 1.50 & 1110 & 1040 \\
\hline & 1.55 & 1040 & 950 \\
\hline & 1.60 & 950 & 810 \\
\hline & 1.65 & 780 & 650 \\
\hline \multirow[t]{5}{*}{$1: 0.004$} & 1.45 & 1020 & 995 \\
\hline & 1.50 & 980 & 920 \\
\hline & 1.55 & 900 & 820 \\
\hline & 1.60 & 810 & 685 \\
\hline & 1.65 & 670 & 540 \\
\hline \multirow[t]{5}{*}{$1: 0.006$} & 1.45 & 930 & 900 \\
\hline & 1.50 & 875 & 820 \\
\hline & 1.55 & 790 & 715 \\
\hline & 1.60 & 700 & 570 \\
\hline & 1.65 & 567 & 460 \\
\hline \multirow[t]{5}{*}{$1: 0.008$} & 1.45 & 860 & 822 \\
\hline & 1.50 & 797 & 720 \\
\hline & 1.55 & 706 & 623 \\
\hline & 1.60 & 603 & 483 \\
\hline & 1.65 & 470 & 350 \\
\hline \multirow[t]{5}{*}{$1: 0.010$} & 1.45 & 780 & 715 \\
\hline & 1.50 & 712 & 630 \\
\hline & 1.55 & 624 & 514 \\
\hline & 1.60 & 516 & 370 \\
\hline & 1.65 & 402 & 278 \\
\hline
\end{tabular}

*Saturated concentration for thiourea is $1.7285 \mathrm{M}$. 
the inner wall of the nucleation cell (glass beaker) was reduced by properly choosing the glass beaker without scratches (tested with a microscope).

\section{Results and discussion}

The measured induction periods are presented in tables 1 and 2. For all systems considered in the present study, the value of $\tau$ decreases and hence the nucleation rate increases as the supersaturation and concentration of doping of the aqueous solution increase. This is similar to the results observed for the ammonium dihydrogen orthophosphate (ADP) doped (in the same ratio considered in the present study) with some inorganic dopants (Premila Rachelin and Mahadevan 1998; Rajesh and Mahadevan 1998; Ramesh and Mahadevan 1998).

Plots of $\ln \tau$ vs $1 / \ln ^{2}(S)$ are presented in figures $1-4$. In the case of $\mathrm{NH}_{4} \mathrm{NO}_{3}$-doped urea, these plots are nearly linear satisfactorily explaining the classical theory for homogeneous nucleation (supposed to be linear according to theory). In the case of $\mathrm{NaNO}_{3}$-doped urea, the plots are again nearly linear. However, significant deviations from

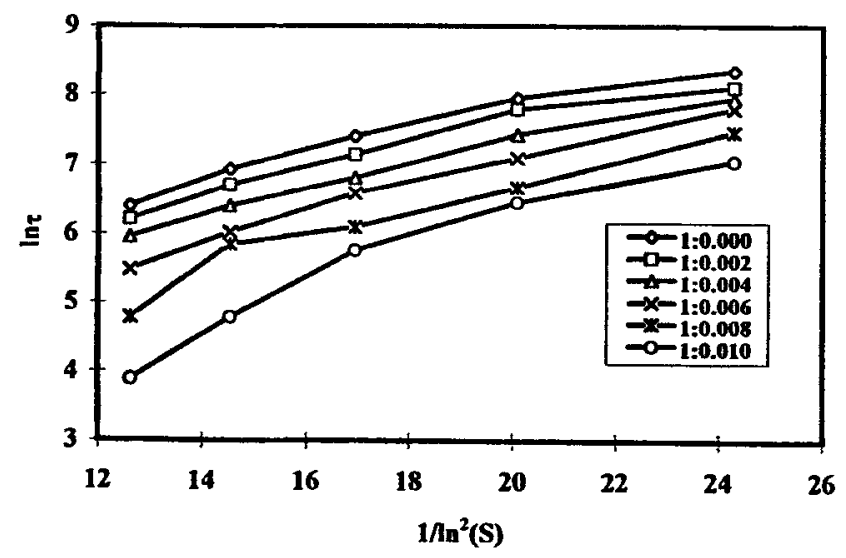

Figure 1. Plots of $\ln \tau$ against $1 / \ln ^{2}(S)$ for $\mathrm{NH}_{4} \mathrm{NO}_{3}$-doped urea.

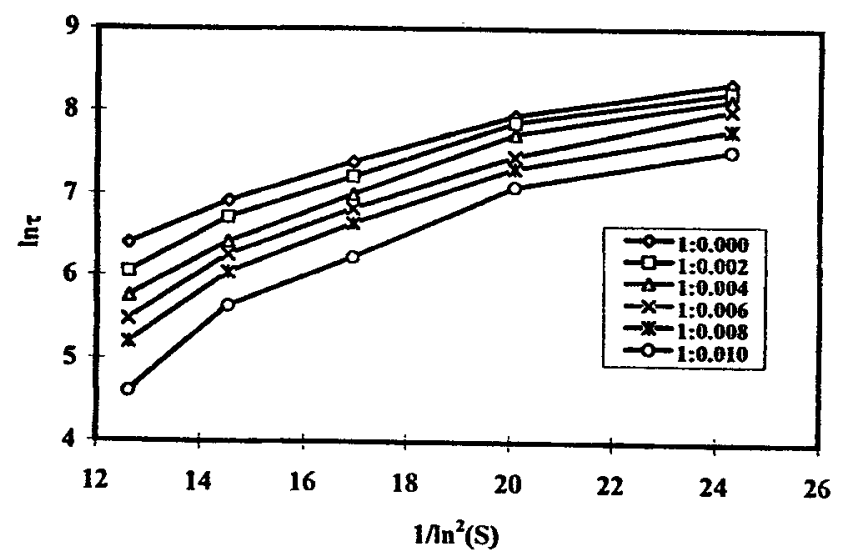

Figure 2. Plots of $\ln \tau$ against $1 / \mathrm{ln}^{2}(S)$ for $\mathrm{NaNO}_{3}$-doped urea. the linearity have been observed for the highest doping concentration at higher supersaturation levels. So, it may be stated that the deviation from linearity at higher supersaturation levels increases with doping concentration and becomes significant at higher doping concentrations. This is similar to that observed for $\left(\mathrm{NH}_{4}\right)_{2} \mathrm{C}_{2} \mathrm{O}_{4} \cdot \mathrm{H}_{2} \mathrm{O}$ doped ADP (Ramesh and Mahadevan 1998). A possible explanation to this result is the occurrence of heterogeneous nucleation caused by the added impurity, $\mathrm{NaNO}_{3}$.

In the case of thiourea, plots of $\ln \tau$ vs $1 / \ln ^{2}(S)$ are not linear at lower supersaturation levels. Such deviations from linearity have also been reported earlier (Nagalingam et al 1980; Shanmugham et al 1984, 1985; Backiyam et al 1991; Premila Rachelin and Mahadevan 1998; Rajesh and Mahadevan 1998). Freeda et al (1997) explained this nonlinearity as not due to difficulties in the induction period measurements but due to the heterogeneous nucleation caused by unwanted impurity particles naturally present in the solvent. There are normally between $10^{6}$ and $10^{8}$ unwanted impurity particles present per $\mathrm{ml}$ of aqueous solution, whatever precautions are taken in performing the experiment

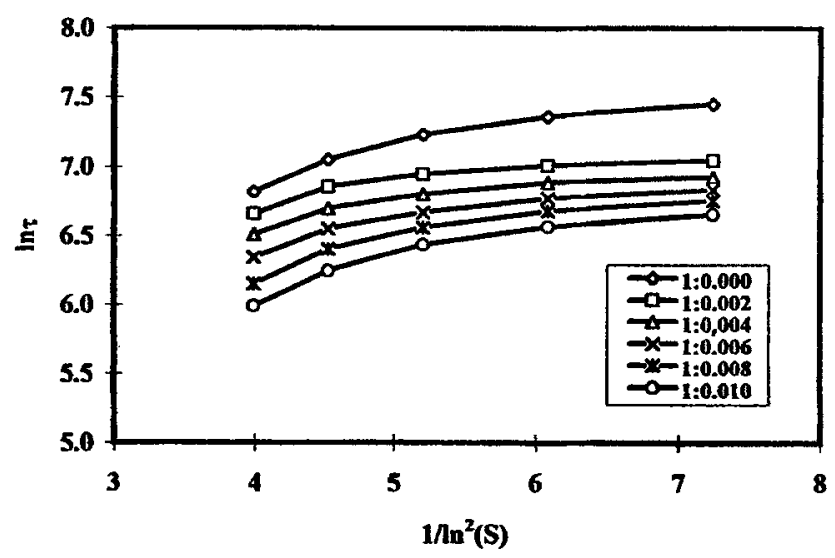

Figure 3. Plots of $\ln \tau$ against $1 / \mathrm{ln}^{2}(S)$ for $\mathrm{NaCl}$-doped thiourea.

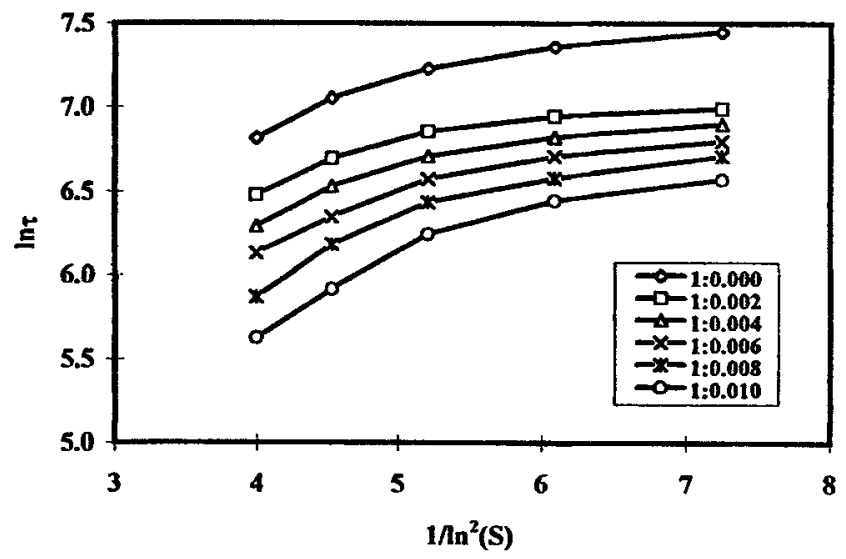

Figure 4. Plots of $\ln \tau$ against $1 / \ln ^{2}(S)$ for KCI-doped thiourea. 
(Shanmugham et al 1984). Linear relationship may be expected at higher supersaturations because the effect of the natural impurity particles present in the solvent is dominated by the presence of a greater amount of solute. Also, for the substance with higher solubility, the higher solubility component may dominate over the unwanted natural impurities present in the solvent more effectively than a substance with lower solubilities. This was observed with $\mathrm{FeSO}_{4} \cdot 7 \mathrm{H}_{2} \mathrm{O}$ (lower solubility and lower linear dependence) and $\mathrm{ZnSO}_{4} \cdot 7 \mathrm{H}_{2} \mathrm{O}$ (higher solubility and greater linear dependence) (Backiyam et al 1991). The present study also shows this. Linear dependence is greater with urea (higher solubility) than with thiourea (lower solubility). The maximum practical limit for the measurement of induction period does not allow the supersaturation to exceed 1.65 in the case of thiourea. Nucleation occurs before the attainment of supersaturation if it is beyond this value. Hence, in order to reduce the effect of these difficulties on the nucleation parameters, the results were obtained using slopes determined in the linear region of the plots of $\ln \tau$ vs $1 / \ln ^{2}(S)$.

The nucleation parameters are presented in tables 3 and 4. The values of $\Delta G$ and $r$ at various supersaturations

Table 3. Nucleation parameters of pure and doped urea crystals.

\begin{tabular}{|c|c|c|c|c|c|c|}
\hline \multirow[b]{2}{*}{ Doping ratio } & \multicolumn{3}{|c|}{ For $\mathrm{NH}_{4} \mathrm{NO}_{3}$-doped urea } & \multicolumn{3}{|c|}{ For $\mathrm{NaNO}_{3}$-doped urea } \\
\hline & $\begin{array}{c}\sigma \\
\left(\mathrm{mJ} \mathrm{m}^{-2}\right)\end{array}$ & $\begin{array}{c}* \Delta G \\
(\mathrm{~kJ} / \mathrm{mole})\end{array}$ & $\begin{array}{c}* r \\
(\mathrm{~nm})\end{array}$ & $\begin{array}{c}\sigma \\
\left(\mathrm{mJ} \mathrm{m}^{-2}\right)\end{array}$ & $\begin{array}{c}{ }^{*} \Delta G \\
(\mathrm{~kJ} / \mathrm{mole})\end{array}$ & $\begin{array}{c}* r \\
(\mathrm{~nm})\end{array}$ \\
\hline Pure urea & $5 \cdot 326$ & 5.985 & 0.667 & $5 \cdot 326$ & 5.985 & 0.667 \\
\hline $1: 0.002$ & $5 \cdot 252$ & $5 \cdot 740$ & 0.658 & $5 \cdot 553$ & 6.784 & 0.696 \\
\hline $1: 0.004$ & $5 \cdot 293$ & 5.875 & 0.663 & $5 \cdot 723$ & $7 \cdot 424$ & 0.717 \\
\hline $1: 0.006$ & $5 \cdot 556$ & 6.794 & 0.696 & 5.856 & 7.958 & 0.734 \\
\hline $1: 0.008$ & 5.854 & 8.035 & 0.733 & 5.918 & $8 \cdot 210$ & 0.741 \\
\hline $1: 0.010$ & $6 \cdot 370$ & $10 \cdot 241$ & 0.798 & $6 \cdot 168$ & 9.296 & 0.773 \\
\hline
\end{tabular}

* $\Delta G$ and $r$ values were calculated at the maximum supersaturation.

Table 4. Nucleation parameters of pure and doped thiourea crystals.

\begin{tabular}{lccccccc}
\hline & \multicolumn{3}{c}{ For NaCl-doped thiourea } & & \multicolumn{3}{c}{ For KCl-doped thiourea } \\
\cline { 2 - 3 } Doping ratio & $\begin{array}{c}\sigma \\
\left(\mathrm{mJ} \mathrm{m}^{-2}\right)\end{array}$ & $\begin{array}{c}* \Delta G \\
(\mathrm{~kJ} / \mathrm{mole})\end{array}$ & $\begin{array}{c}* r \\
(\mathrm{~nm})\end{array}$ & $\begin{array}{c}\sigma^{*} \\
\left(\mathrm{~mJ} \mathrm{~m}^{-2}\right)\end{array}$ & $\begin{array}{c}* \Delta G \\
(\mathrm{~kJ} / \mathrm{mole})\end{array}$ & $\begin{array}{c}{ }^{*} r \\
(\mathrm{~nm})\end{array}$ \\
\hline Pure thiourea & 5.405 & 2.968 & 0.467 & 5.405 & 2.968 & 0.467 \\
$1: 0.002$ & 4.805 & 2.085 & 0.415 & & 5.249 & 2.720 & 0.453 \\
$1: 0.004$ & 4.907 & 2.221 & 0.424 & & 5.370 & 2.912 & 0.464 \\
$1: 0.006$ & 5.053 & 2.425 & 0.436 & & 5.479 & 3.093 & 0.473 \\
$1: 0.008$ & 5.486 & 3.104 & 0.474 & & 5.931 & 3.922 & 0.512 \\
$1: 0.010$ & 5.705 & 3.491 & 0.493 & 6.182 & 4.441 & 0.534 \\
\hline
\end{tabular}

* $\Delta G$ and $r$ values were calculated at the maximum supersaturation.

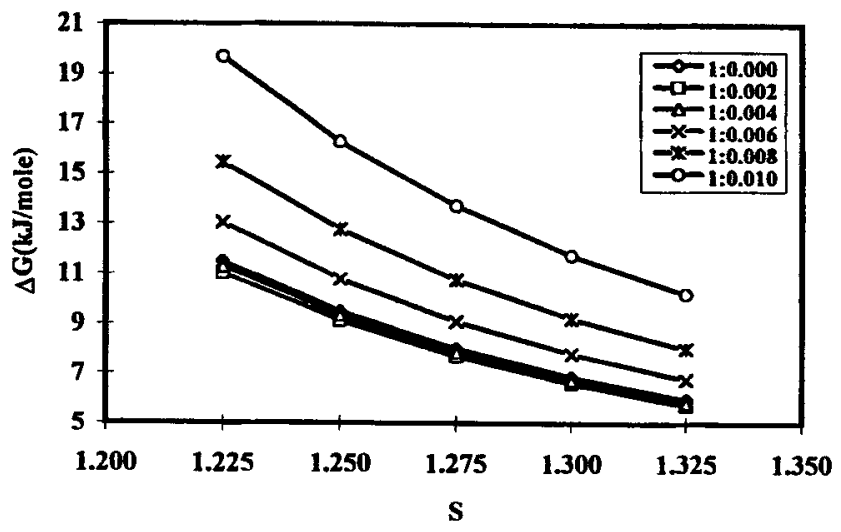

Figure 5. Dependence of energy of formation of critical nucleus on supersaturation for $\mathrm{NH}_{4} \mathrm{NO}_{3}$-doped urea.

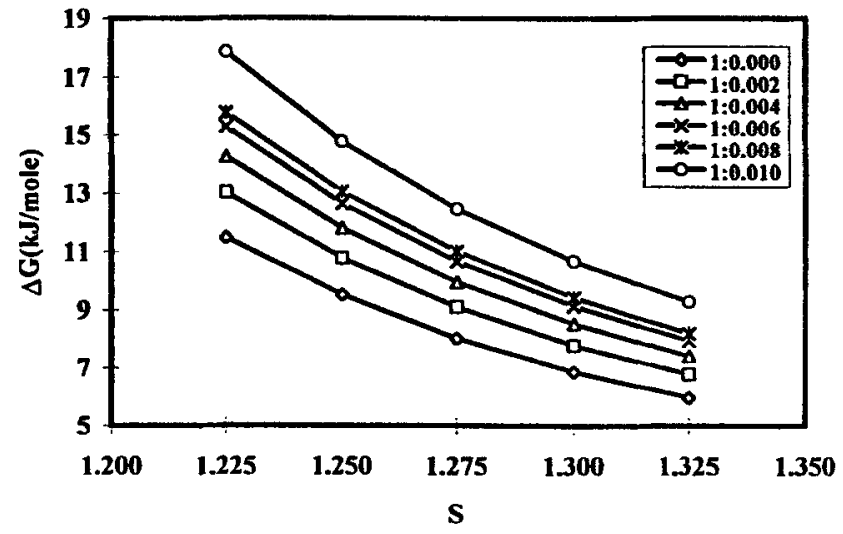

Figure 6. Dependence of energy of formation of critical nucleus on supersaturation for $\mathrm{NaNO}_{3}$-doped urea. 


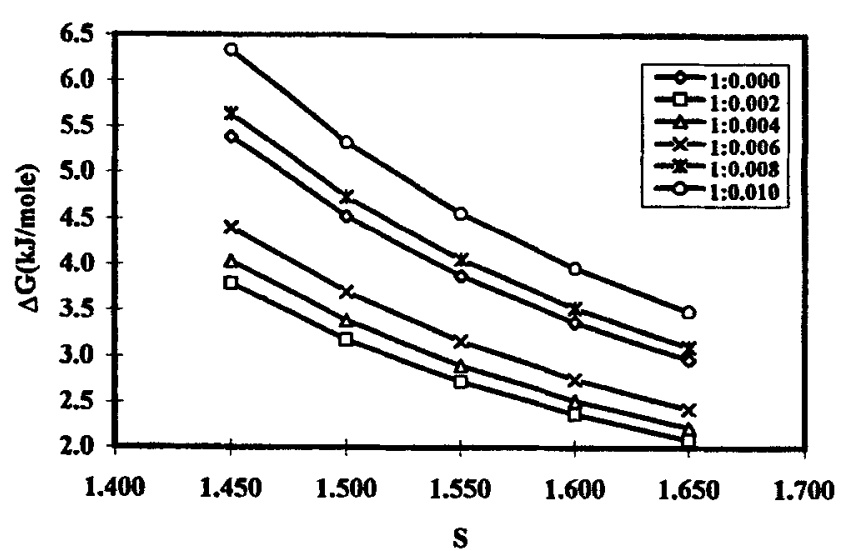

Figure 7. Dependence of energy of formation of critical nucleus on supersaturation for $\mathrm{NaCl}$-doped thiourea.

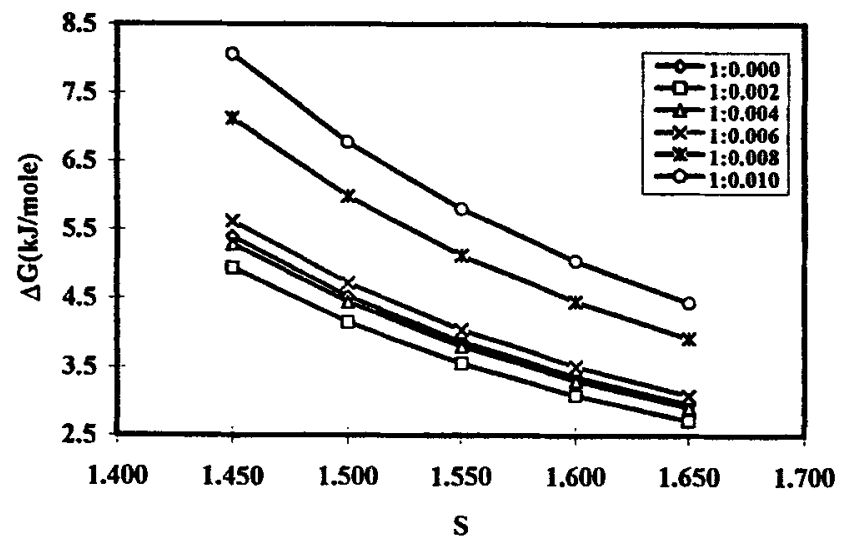

Figure 8. Dependence of energy of formation of critical nucleus on supersaturation for $\mathrm{KCl}$-doped thiourea.

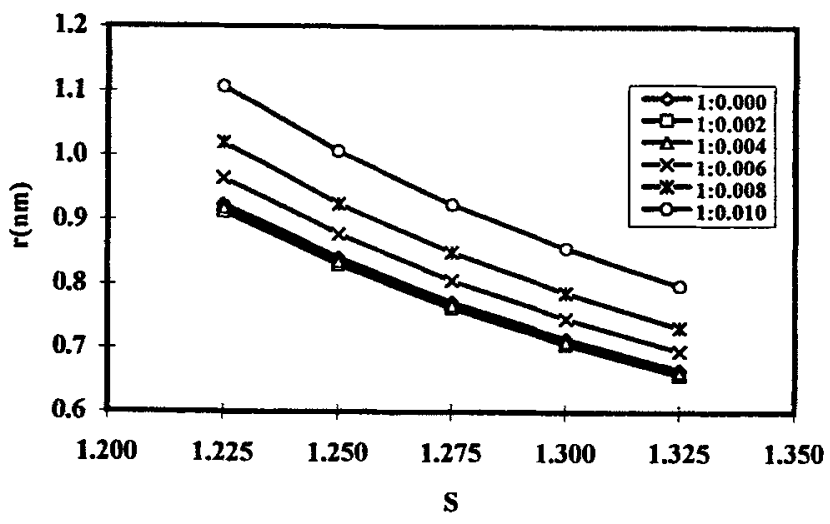

Figure 9. Dependence of radius of critical nucleus on supersaturation for $\mathrm{NH}_{4} \mathrm{NO}_{3}$-doped urea.

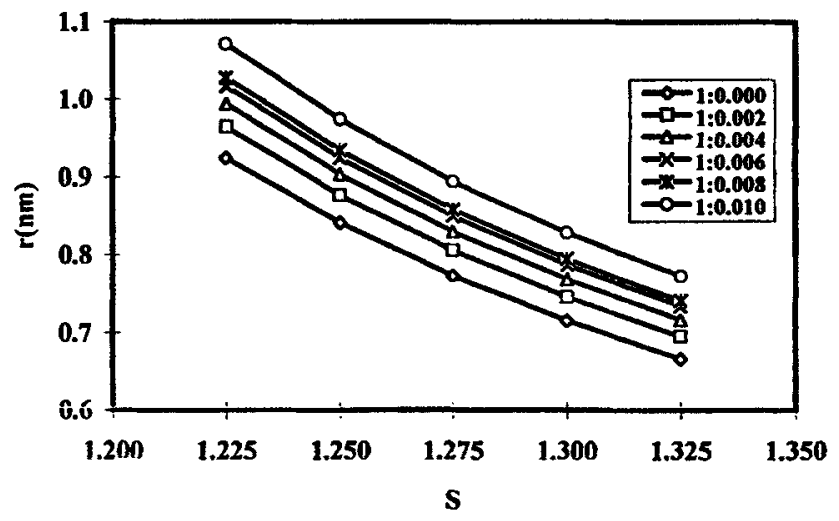

Figure 10. Dependence of radius of critical nucleus on supersaturation for $\mathrm{NaNO}_{3}$-doped urea.

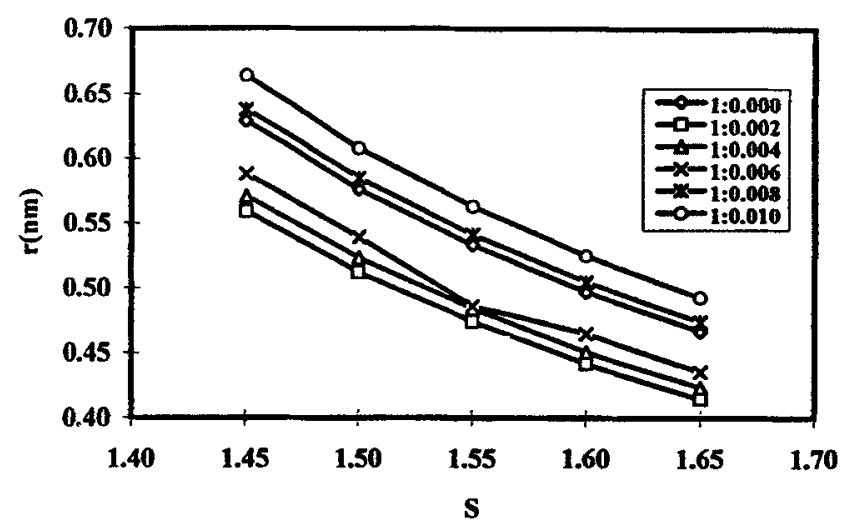

Figure 11. Dependence of radius of critical nucleus on supersaturation for $\mathrm{NaCl}$-doped thiourea.

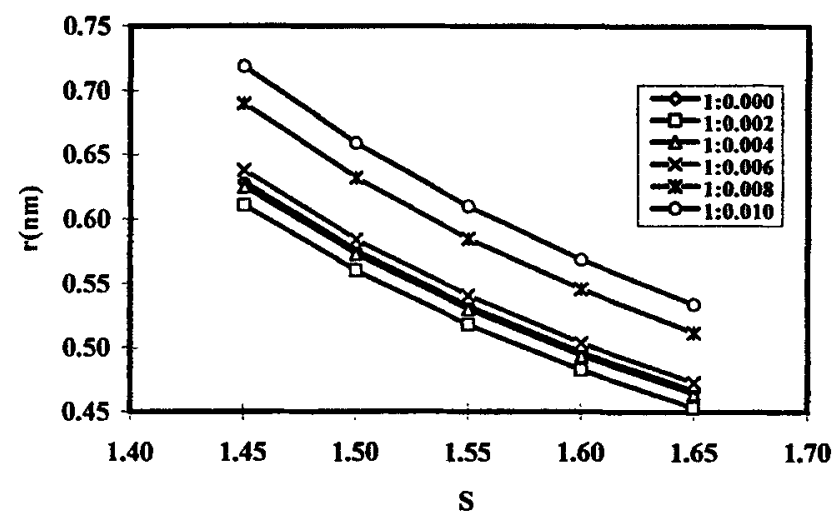

Figure 12. Dependence of radius of critical nucleus on supersaturation for $\mathrm{KCl}$-doped thiourea. 
have also been calculated for all crystals and the results are presented in figures 5 to 12 . It was observed that the values of $\Delta G$ and $r$ decreased when supersaturation increased. This result is similar to that observed by previous authors for their systems.

For all systems considered in the present study, the nucleation parameters $(\sigma, \Delta G$ and $r)$ increased with increase in concentration of doping in the aqueous solution (tables 3 and 4 and figures 5-12). However, the nucleation parameters observed for systems having urea : $\mathrm{NH}_{4} \mathrm{NO}_{3}$ ratios $1: 0.002$ and 1:0.004 are less than that observed for pure urea. Similarly, the nucleation parameters observed for systems having thiourea : $\mathrm{NaCl}$ ratios $1: 0.002,1: 0.004$, and $1: 0.006$ and thiourea : $\mathrm{KCl}$ ratios $1: 0.002$ and $1: 0.004$ are less than that observed for pure thiourea. While this cannot be due to an experimental error we may attribute this to the unpredictable situation caused by inorganic impurities. However, the exact reason is still to be understood.

\section{Conclusions}

Induction period was measured for urea doped separately with $\mathrm{NH}_{4} \mathrm{NO}_{3}$ and $\mathrm{NaNO}_{3}$ and thiourea doped separately with $\mathrm{NaCl}$ and $\mathrm{KCl}$ by the direct vision method at $35^{\circ} \mathrm{C}$ with five selected supersaturations. The induction period decreased with increase in supersaturation and doping concentration. The present study indicates that nucleation parameters calculated based on classical theory for homogeneous crystal nucleation increase with increase in doping concentration. The classical theory for homogeneous crystal nucleation is well explained by the experimentally observed linear relationship between $\ln \tau$ and $1 / \ln ^{2}(S)$.

\section{References}

Backiyam M, Anitha R Nair and Mahadevan C 1991 Indian J. Pure Appl. Phys. 29455

Freeda T H, Rajesh N P and Mahadevan C 1997 Recent developments in crystal growth (Karaikudi: Alagappa University) Vol. 1, p. 68

John A D (ed.) 1979 Lange's handbook of chemistry (New York: McGraw Hill) 12th ed.

Mullin J W 1993 Crystallization (Oxford: Butterworth-Heinemann)

Nagalingam S, Vasudevan S, Ramasamy P and Laddha G S 1980 Kristall. Tech. 151151

Premila Rachelin Y and Mahadevan C 1998 Indian J. Pure Appl. Phys. 3638

Rajesh N P and Mahadevan C 1998 J. Indian Chem. Soc. 75 307

Ramesh R and Mahadevan C 1998 Bull. Mater. Sci. 21287

Shanmugham M, Gnanam F D and Ramasamy P 1984 J. Mater. Sci. 192837

Shanmugham M, Gnanam F D and Ramasamy P 1985 J. Mater. Sci. Lett. 4746 